\title{
Hepatitis B Virus Infection in Pregnant Women, in Al Fashir Town, North Darfur State, Sudan
}

\author{
Ragaa Abo El Gasim ${ }^{*}$, Nada Eltayeb ${ }^{2}$, Isam El Khidir ${ }^{3}$ \\ ${ }^{1}$ Department of Microbiology, Faculty of Medicine, University of Al Fashir, Al Fashir, Sudan \\ ${ }^{2}$ Al Neelain Medical Research Centre, Faculty of Medicine, Al Neelain University, Khartoum, Sudan \\ ${ }^{3}$ Department of Microbiology and Parasitology, Faculty of Medicine, University of Khartoum, Khartoum, Sudan \\ Email: *ragagasim@yahoo.com, nadatayeb123@yahoo.com, isamelkhidir@gmail.com
}

How to cite this paper: El Gasim, R.A., Eltayeb, N. and El Khidir, I. (2019) Hepatitis B Virus Infection in Pregnant Women, in Al Fashir Town, North Darfur State, Sudan. Open Journal of Medical Microbiology, 9, 28-36.

https://doi.org/10.4236/ojmm.2019.91004

Received: October 22, 2018

Accepted: February 26, 2019

Published: March 1, 2019

Copyright $\odot 2019$ by author(s) and Scientific Research Publishing Inc. This work is licensed under the Creative Commons Attribution International License (CC BY 4.0).

http://creativecommons.org/licenses/by/4.0/

\section{(c) (i) Open Access}

\begin{abstract}
Background: Sudan is a highly endemic country for hepatitis B virus (HBV). Screening for HBV during pregnancy may help to decide on appropriate antiviral therapy and the institution of steps to minimize vertical transmission to the newborns. Of the epidemiological studies carried in different regions of Sudan, few are available regarding pregnant women. In Darfur region such data is absent, so our aim was to evaluate seroprevalence of HBV among antenatal care attendants in Al Fashir town. Method: A cross sectional study was conducted between 2013 and 2015. Blood samples were collected from 900 pregnant women attending antenatal clinics in Al Fashir town. Plasma was separated and tested for markers of $\mathrm{HBV}$ ( $\mathrm{HBcAb}, \mathrm{HBsAg}, \mathrm{HBeAg}, \mathrm{HBeAb}$ ) using ELISA. Sociodemographic, obstetrics and medical data were collected using structured questionnaires. Results: AntiHBc was detected in $46 \%$ and $\mathrm{HBsAg}$ was detected in $18 \%$ of study population. $\mathrm{HBeAg}$ and $\mathrm{HBeAb}$ frequencies were found to be $2.6 \%$ and $37.7 \%$ among positive HBsAg pregnant women. There was significant association between residence, income, occupation, bloodletting and ear piercing with HBV infection $(\mathrm{P}<0.05)$. Conclusion: The results of the study suggest that HBsAg has a high prevalence among the pregnant women in Al Fashir town, North Darfur State. So, to minimize vertical transmission, antenatal women must be routinely screened for HBV.
\end{abstract}

\section{Keywords}

HBV, Pregnant Women, North Darfur State, Al Fashir

\section{Background}

Hepatitis B is a well-recognized global public health problem. It was estimated 
that approximately 2 billion people have serological evidence of past or present HBV infection and more than 350 million have chronic infections [1], these chronically infected persons are at high risk of death from cirrhosis of the liver and cancer, diseases that kill about one million persons each year [1].

Pregnant women with HBV represent a major reservoir of the virus in the community. Mother to child transmission of HBV is the main transmission route and contributes significantly to chronic HBV infection [2]. Of estimated 350 million individuals chronically infected with HBV worldwide, it is generally accepted that at least $50 \%$ acquired their infections either perinatally or in early childhood, especially in countries where HBV is endemic [3]. Perinatal vertical transmission is the most common mode of transmission worldwide [4]. High maternal viral load and maternal serum HBV envelope antigen (HBeAg) positivity increase the risk of perinatal transmission [5]. Therefore investigating seroprevalence of $\mathrm{HBV}$ surface antigen ( $\mathrm{HBsAg}$ ) in pregnancy in different settings is needed to prevent vertical transmission.

In Sudan, previous reports indicate that hepatitis B is hyperendemic and infection with HBV is an important cause of chronic liver disease [6] [7]. Seroprevalence of $\mathrm{HBV}$ infections among pregnant women may be a good indicator of general population prevalence and a determinant of vaccination policy [8] [9].

Although much recent data are available on the epidemiology of HBV among pregnant women in different African countries [10] [11] [12], few published data are available from Sudan, such that reported early by Elsheikh et al. [13], Osman et al. [14], Abuelgasim and Baraka in central Sudan [15].

Such data are fundamental for health planners and care givers for evidencebased intervention. The present study aimed to evaluate the prevalence of HBV among the pregnant women in Al Fashir town, North Darfur State and to identify risk factors that may lead to acquisition of HBV among these women.

\section{Ethical Considerations}

The study was approved by the Ethics committee of Al Neelain Medical Research, Faculty of Medicine, Al Neelain University and informed consent was obtained from all participants before collection of samples.

\subsection{Inclusion Criterion}

Any pregnant women who gave consent to participate in the study.

\subsection{Exclusion Criterion}

Pregnant women who did not accept to be part of the study.

\section{Method}

This is a descriptive cross sectional study carried out between 2013 and 2015. Nine hundreds pregnant women, attending Al-Fashir new hospital, a reference hospital for obstetrics and gynaecology, and peripheral health care centers in $\mathrm{Al}$ 
Fashir town were enrolled.

Blood samples were collected from pregnant women in Ethylene Di-amine Tetra-acetic Acid (EDTA) tubes; the samples were allowed to clot at room temperature and centrifuged at $3000 \mathrm{rpm}$ for 5 minutes to separate the plasma and stored at $-20^{\circ} \mathrm{C}$. A structured questionnaire was applied to gather sociodemographic characteristics (age, residence, education, income and occupation) and the possible risk factors (e.g. history of surgery, dental manipulation, tattooing, unsafe injection, caesarian section, abortion, jaundice, blood transfusion, ear piercing, bloodletting and vaccination).

The Plasma samples were tested for the $\mathrm{HBV}$ markers (HBcAb, $\mathrm{HBsAg}$, $\mathrm{HBeAg}, \mathrm{HBeAb}$ ) respectively, using the in vitro ELISA diagnostic kit (Beijing Wantai Biological Pharmacy Enterprise Co., Ltd. China), according to the manufacture's recommendations.

Samples were first tested for $\mathrm{HBcAb}$. Positive anti-core samples were tested for HBsAg. One hundred fifty three (153) and one hundred fifty four (154) out of the samples that were positive for HBsAg were tested for $\mathrm{HBeAg}$ and $\mathrm{HBeAb}$ respectively.

\section{Statistical Analysis}

Data were multi-checked, coded, entered and analyzed using statistical package for social sciences (SPSS for Windows version 16.0). Chi - square and Fisher Exact test were used to test if there is significant association between occurrence of HBV and variables grouped in more than one category as in demographic data (age, residence, education, income and occupation). Using MedCalc statistical software prevalence odds ratio (OR) with their 95\% confidence intervals (CI) was calculated to estimate the magnitude of the association between HBsAg positivity and the study variables with answers "yes" or "no", data set constructed in $2 \times 2$ table as for medical, obstetrical and the other possible risk factors. A $\mathrm{p}$ value $\leq 0.05$ was considered significant.

\section{Results}

\subsection{General Characteristics}

Most of the pregnant women enrolled in the study were in the age group 15 - 35 $(774,86 \%)$, mean age \pm SD was $26.93 \pm 6.68$. The majority of the women residing in the city $(581,64.6 \%)$ and mostly were housewives $(783,87 \%)$. Mostly were in low income class $(810,90 \%)$ and $(501,55.7 \%)$ had only primary education.

\subsection{Seroprevalence of HBV Markers}

Among the 900 pregnant women enrolled in the study, HBcAb was detected in $46 \%$ (414/900). One hundred sixty two pregnant women were confirmed positive for HBsAg 18\% (162/900). HBeAg was detected in $2.6 \%(4 / 153)$, where as $\mathrm{HBeAb}$ was found in $37.7 \%$ (58/154) (Table 1 ).

Significant association with the disease was reported in cases of residence $(\mathrm{P}=$ 
Table 1. Prevalence of the HBV markers tested among the study population.

\begin{tabular}{cccc}
\hline HBV Marker & $\begin{array}{c}\text { Positive } \\
\text { No. (\%) }\end{array}$ & $\begin{array}{c}\text { Negative } \\
\text { No. }(\%)\end{array}$ & $\begin{array}{c}\text { Total No } \\
\text { tested }\end{array}$ \\
\hline HBcAb & $414(46)$ & $486(54)$ & 900 \\
HBsAg & $162(18)$ & $252(28)$ & 414 \\
HBeAg & $4(2.61)$ & $149(97.39)$ & 153 \\
HBeAb & $58(37.66)$ & $96(62.34)$ & 154 \\
\hline
\end{tabular}

0.01), income $(P=0.01)$, occupation $(P=0.02)$. Ear piercing $(\mathrm{OR}=1.9,95 \% \mathrm{CI}$ $=1.3-2.9, \mathrm{P}=0.00)$ and bloodletting $(\mathrm{OR}=0.2,95 \% \mathrm{CI}=0.1-0.9, \mathrm{P}=0.02)$ were found to be the significant risk factor for HBV infection (Table 2).

\section{Discussion}

The present findings are believed to be the first data of HBV seroprevalence among pregnant women in North Darfur State. The study confirmed that extremely high $\mathrm{HBV}$ rates exist in the study area evidenced by high seroprevalence of anti-HBcAg (46\%) and HBsAg (18\%) among the pregnant women. This rate is highest than the rates reported among pregnant women at Umdurman Maternity Hospital (5.6\%) and Khartoum teaching Hospital (7.5\%) [13] [15]. However, it is in agreement with early reports in El Gazira State (18.7\%) by Hyams et al. [16] and 17.3\% from laboratory technical staff by El shafie [17].

The seroprevalence of HBsAg among these pregnant women is higher than the prevalence of this marker among the Health care workers reported in Khartoum teaching hospitals (4.89\%) by Elduma and Saeed [18] and 6\% by El Mukashfie et al. [19].

Also our findings are higher than those reported from other populational groups in different regions of Sudan; e.g. 6.25\% among blood donors in Nyala town, South Darfur by Abou [20], 6.9\% among population of Um Zukra village, El Gazira State by Mudawi [21].

The probable explanation for the higher prevalence of HBsAg in our study in comparison to the previous reports in Khartoum; may be the usage of the rapid diagnostic tests which are less sensitive than ELISA in most of the mentioned studies, improvement of blood screening procedures and the introduction of the HBV vaccination program among the health care workers.

The seroprevalence of HBsAg among our pregnant women is also higher than that reported in other African countries; $10.7 \%$ in Mauritania [11], 12.5\% in Nigeria [12], 12.6\% in Ghana [22].

The seroprevalence variation observed outside the country as compared to our study might be attributed to geographical variations, cultural and behavioral differences regarding the possible risk factors of $\mathrm{HBV}$ infection.

The high prevalence of HBsAg observed in this study could be an indication that pregnant women serve as a very important reservoir to fuel the HBV epidemic in the general population. 
Table 2. P-value and odds ratio analysis of the possible risk factors for HBsAg among the study population.

\begin{tabular}{|c|c|c|c|}
\hline Variable & P-Value & Odd Ratio & 95\% Confidence Interval \\
\hline Age & 0.67 & & \\
\hline Tribe & 0.34 & & \\
\hline Residence & 0.01 & & \\
\hline Occupation & 0.02 & & \\
\hline Educational Level & 0.69 & & \\
\hline Income & 0.01 & & \\
\hline Dental Manipulation & 0.60 & 0.8 & $0.4-1.6$ \\
\hline Tattooing & 0.97 & 1.0 & $0.5-2.2$ \\
\hline Surgery & 0.32 & 0.7 & $0.3-1.4$ \\
\hline Unsafe Injection & 0.25 & 0.3 & $0.0-6.3$ \\
\hline Caesarian Section & 0.38 & 1.3 & $0.7-2.4$ \\
\hline Abortion & 0.22 & 0.8 & $0.5-1.2$ \\
\hline Jaundice & 0.82 & 0.9 & $0.5-1.6$ \\
\hline Blood Letting & 0.02 & 0.2 & $0.1-0.9$ \\
\hline Ear piercing & 0.00 & 1.9 & $1.3-2.9$ \\
\hline Blood transfusion & 0.25 & 0.6 & $0.3-1.4$ \\
\hline Vaccination & 0.80 & 0.9 & $0.3-2.5$ \\
\hline
\end{tabular}

$\mathrm{HBeAg}$ presence is an important indicator of transmissibility. Despite the fact that high prevalence of HBsAg was observed in this study, HBeAg was found in $2.6 \%$ of the positive HBsAg pregnant women. This is far low from what was early reported from rural surveillance in El Gazira region [16]. Since that the low prevalence of e Ag results in lack of perinatal transmission. This indicates that vertical transmission is not important in our study population. Moreover, finding of $\mathrm{HBeAb}$ indicates low transmissibility, in this study $\mathrm{HBeAb}$ was found in $37.7 \%$ of the HBsAg positive women.

The current study showed that residence, income and occupation were significantly associated with HBsAg seropositivity ( $\mathrm{p}=0.01,0.01,0.02)$ respectively (Table 2).

In our study, most of the women were residence in town (64\%); mostly displaced and came to live on the periphery of the city following the conflict in this region; they belonging to poor socioeconomic and low educational status. In this study the prevalence of HBsAg was higher in women from urban (44.4\%) than in rural area (36.2\%). As stated by Abongwa and Keneth; this may be due to the higher rates of risky life-style practices in most urban towns and the increased migration from rural to urban for purpose of education or employment [23] (Table 3).

In this study significant association was found between income and HBsAg 
seroprevalence, since that $90 \%$ of our study population was in low class income, a high carrier rate of HBsAg was noticed among them $40.4 \%(145 / 359, \mathrm{P}=0.01)$ (Table 4).

As stated that occupation is a known predisposing factor for $\mathrm{HBV}$ infection. [24] However, in our study most of the women were housewives (87\%); they were more affected than other categories, HBsAg positivity was found in $41.9 \%$ $(149 / 356)$ of them. This indicates that housewives need to be oriented about sexual diseases and their transmission. Whereas highest rate was noticed in women who work in the medical field (60\%) although they represent only $1 \%$ of the study population, however, their number was not representative in the study population to make reasonable judgment (Table 5).

Ear piercing was found to be 1.9 times high risk factor for the HBV exposure $(\mathrm{OR}=1.9,95 \% \mathrm{CI}=1.3-2.9, \mathrm{P}=0.00)$. During the interview most of the women said that they used plant thorns to make opening in the ear. Regarding this, contamination may contribute in exposure to $\mathrm{HBV}$.

Table 3. Distribution of HBsAg positive pregnant women according to their residence.

\begin{tabular}{cccc}
\hline \multirow{2}{*}{ Residence } & No tested & \multicolumn{2}{c}{ HBsAg + ve } \\
\cline { 3 - 4 } & & 114 & $\%$ \\
\hline Urban & 257 & 38 & 44.36 \\
Rural & 105 & 0 & 36.11 \\
Others & 14 & 152 & 00.00 \\
Total & 376 & & 40.43 \\
\hline
\end{tabular}

Table 4. Distribution of HBsAg positive pregnant women according to their income.

\begin{tabular}{cccc}
\hline \multirow{2}{*}{$\begin{array}{c}\text { Income } \\
\text { level }\end{array}$} & No. tested & \multicolumn{2}{c}{ HBsAg + ve } \\
\cline { 3 - 4 } & 359 & Freq & $\%$ \\
\hline Low & 15 & 145 & 40.39 \\
Medium & 1 & 8 & 53.33 \\
High & 375 & 0 & 00.00 \\
Total & 153 & 40.00 \\
\hline
\end{tabular}

Table 5. Distribution of HBsAg positive pregnant women according to their occupation.

\begin{tabular}{cccc}
\hline \multirow{2}{*}{ Occupation } & No tested & \multicolumn{2}{c}{ HBsAg + ve } \\
\cline { 3 - 4 } & & 149 & 41.85 \\
\hline Housewives & 356 & 0 & 00.00 \\
Employer & 14 & 3 & 60 \\
Medical personnel & 5 & 0 & 00.00 \\
Workers & 2 & 152 & 40.32 \\
Total & 377 &
\end{tabular}


Bloodletting was also found to be a risk factor for the HBV exposure $(\mathrm{OR}=$ $0.2,95 \% \mathrm{CI}=0.1-0.9, \mathrm{P}=0.02$ ). Since that bloodletting is a traditional healing practiced by some people in this area without efficient sterilization, hence contamination may contribute in virus transfer.

\subsection{Limitations of the Study}

Regarding the high prevalence of HBsAg in the current study; the population investigated consisted only of women who were able to access antenatal care, and the prevalence reported here may have underestimated the true prevalence among pregnant women in the larger community.

\subsection{Conclusion}

Seroprevalence of HBV among antenatal women in Al Fashir town is high. Increasing awareness of transmission of $\mathrm{HBV}$, vaccination and regular screening of pregnant women for hepatitis viruses are recommended.

\section{Funding}

The research is partially funded by the Ministry of Higher Education and Scientific Research, Sudan.

\section{Conflicts of Interest}

The authors declare that they have no competing interests.

\section{References}

[1] Hepatitis B: World Health Organization Fact Sheet 204. 2000: World Health Organization. http://www.who.int/mediacentre/factsheets/fs204/en/

[2] Michielsen, P. and Van Damme, P. (1999) Viral Hepatitis and Pregnancy. Acta Gastro-Enterologica Belgica, 62, 21-29.

[3] Alter, M.J. (2003) Epidemiology of Hepatitis B in Europe and Worldwide. Journal of Hepatology, 39, 64-69. https://doi.org/10.1016/S0168-8278(03)00141-7

[4] Mast, E.E., Weinbaum, C.M., Fiore, A.E., Alter, M.J., Bell, B.P., Finelli, L., et al. (2006) A Comprehensive Immunization Strategy to Eliminate Transmission of Hepatitis B Virus Infection in the United States: Recommendations of the Advisory Committee on Immunization Practices (ACIP) Part II: Immunization of Adults. MMWR Recommendations and Reports, 55, 1-3.

[5] Chowdhury, S.D. and Eapen, C.E. (2009) Perinatal Transmission of Hepatitis B. Hepatitis B Annual, 6, 80-88.

[6] Mudawi, H.M. (2008) Epidemiology of Viral Hepatitis in Sudan. Clinical and Experimental Gastroenterology, 1, 9-13. https://doi.org/10.2147/CEG.S3887

[7] Omer, R.E., Van't Veer, P., Kadaru, A.M., Kampman, E., El Khidir, I.M., Fedail, S.S. and Kok, F.J. (2001) The Role of Hepatitis B and Hepatitis C Viral Infections in the Incidence of Hepatocellular Carcinoma in Sudan. Transactions of the Royal Society of Tropical Medicine and Hygiene, 95, 487-491. https://doi.org/10.1016/S0035-9203(01)90013-6

[8] Saphonn, V., Hor, L.B., Ly, S.P., Chhuon, S., Saidel, T. and Detels, R. (2002) How 
Well Do Antenatal Clinic (ANC) Attendees Represent the General Population? A Comparison of HIV Prevalence from ANC Sentinel Surveillance Sites with a Population-Based Survey of Women Aged 15 - 49 in Cambodia. International Journal of Epidemiology, 31, 449-455.

[9] Fabiani, M., Fylkesnes, K., Nattabi, B., Ayella, E.O. and Declich, S. (2003) Evaluating Two Adjustment Methods to Extrapolate HIV Prevalence from Pregnant Women to the General Female Population in Sub-Saharan Africa. AIDS, 17, 399 405. https://doi.org/10.1097/00002030-200302140-00014

[10] Tiruneh, M. (2008) Seroprevalence of Multiple Sexually Transmitted Infections among Antenatal Clinic Attendees in Gondar Health Center, Northwest Ethiopia. Ethiopian Medical Journal, 46, 359-366.

[11] Mansour, W., Malick, Z.F., Sidiya, A., Ishagh, E., Chekaraou, M.A., et al. (2012) Prevalence, Risk Factors, and Molecular Epidemiology of Hepatitis B and Hepatitis Delta Virus in Pregnant Women and in Patients in Mauritania. Journal of Medical Virology, 84, 1186-1198. https://doi.org/10.1002/jmv.23336

[12] Ugbebor, O., Aigbirior, M., Osazuwa, F., Enabudoso, E. and Zabayo, O. (2011) The Prevalence of Hepatitis B and C Viral Infections among Pregnant Women. North American Journal of Medicine and Science, 3, 238-241. https://doi.org/10.4297/najms.2011.3238

[13] Elsheikh, R.M., Daak, A.A., Elsheikh, M.A., Karsany, M.S. and Adam, I. (2007) Hepatitis B Virus and Hepatitis C Virus in Pregnant Sudanese Women. Virology Journal, 4, 104. https://doi.org/10.1186/1743-422X-4-104

[14] Osman, A.M.M., Mirghani, O.A., Gasim, G.I. and Adam, I. (2014) Hepatitis B Virus, Hepatitis $\mathrm{C}$ Virus and Human Immunodeficiency Virus Infections among Pregnant Women in Central Sudan. Sudan Journal of Medical Sciences, 9.

[15] Abuelgasim, M.H. and Baraka, M.B.K. (2015) Prevalence of Hepatitis B Infection among Pregnant Women at Khartoum Teaching Hospital, Sudan. Journal of US China Medical Science, 12, 58-63.

[16] Hyams, K.C., al-Arabi, M.A., al-Tigani, A.A., Messiter, J.P., Al-Gaali, A.A. and George, J.F. (1989) Epidemiology of Hepatitis B in the Gezira Region of Sudan. The American Journal of Tropical Medicine and Hygiene, 40, 200-206. https://doi.org/10.4269/ajtmh.1989.40.200

[17] Elshafie, S.S. (1992) The Prevalence of Hepatitis B Surface Antigen in the Gezira (Sudan). African Journal of Medicine and Medical Sciences, 21, 61-63.

[18] Elduma, A.H. and Saeed, N.S. (2011) Hepatitis B Virus Infection among Staff in Three Hospitals in Khartoum, Sudan. The Eastern Mediterranean Health Journal, 17, 474-478. https://doi.org/10.1016/j.ssci.2011.12.028

[19] Elmukashfi, T.A., Elkhidir, I.M., Ibrahim, O.A., Bashir, A.A. and Awad Elkarim, M.A. (2012) Hepatitis B Virus Infection among Health Care Workers in Public Teaching Hospitals in Khartoum State, Sudan. Safety Science, 50, 1215-1217.

[20] Abou, M.A., Eltahir, Y.M. and Ali, A.S. (2009) Seroprevalence of Hepatitis B Virus and Hepatitis C Virus among Blood Donors in Nyala, South Darfur, Sudan. Virology Journal, 6, 146. https://doi.org/10.1186/1743-422X-6-146

[21] Mudawi, H.M., Smith, H.M., Rahoud, S.A., Fletcher, I.A., Saeed, O.K. and Fedail, S.S. (2007) Prevalence of Hepatitis B Virus Infection in the Gezira State of Central Sudan. Saudi Journal of Gastroenterology, 13, 81-83. https://doi.org/10.4103/1319-3767.32182

[22] Candotti, D., Danso, K. and Allain, J.P. (2007) Maternofetal Transmission of Hepatitis B Virus Genotype E in Ghana, West Africa. Journal of General Virology, 88, 
2686-2695. https://doi.org/10.1099/vir.0.83102-0

[23] Abongwa, L.E. and Kenneth, P. (2016) Assessing Prevalence and Risk Factors of Hepatitis B Surface Antigen amongst Pregnant Women Attending Antenatal Clinic in the Northwest Region of Cameroon. European Journal of Research in Medical Sciences, 4, 32-43.

[24] Ajayi, A.O., Komolafe, A.O. and Ajumobi, K. (2007) Sero-Prevalence of Hepatitis B among Health Care Workers in a Nigerian Tertiary Health Institution. Nigerian Journal of Clinical Practice, 10, 287-289. 